\title{
—Hrvoje Gračanin-
}

\section{Bellum Batonianum i Bellum Liudewiticum: dodirnice i razilaznice*}

\begin{abstract}
Analiziraju se paralele između batonskog rata i rata protiv donjopanonskog kneza Ljudevita na temelju antičkih, odnosno ranosrednjovjekovnih vrela. Naročita pozornost posvećuje se prikazima situacija i izrazima koje su autori zapisa rabili opisujući oba rata, kako bi se uočio povijesnospisateljski i ideološki obrazac te međuovisnost narativa. Evidentiraju se i razlike koje su posljedica različitih historiografskih žanrova i ideoloških potreba. Napokon, uspoređuju se i praktične pojavnosti oba rata prema dostupnim vrelima. Osnovicu za usporedbu čine navodi iz Godišnjakâ Franačkog Kraljevstva (Annales regni Francorum) i Života Ludovikova (Vita Hludowici imperatoris) koji su sastavljeni u prvoj polovini 9. stoljeća i najiscrpnija su vrela za ustanak donjopanonskog kneza Ljudevita, odnosno iz Rimske povijesti (Historia Romana) Veleja Paterkula i Života cezarâ (De vita Caesarum) Svetonija Trankvila (rano 1. i rano 2. stoljeće), djela koja donose dragocjene podatke o ustanku Batonâ. Naročito se istražuje veza između franačkih vrela i Svetonijevih carskih životopisa, budući da je povijesnospisateljska tradicija karolinške renesanse nadahnuće pronašla upravo u Svetonijevoj biografskoj povjesnici (valja se prisjetiti Einhardova Života Karla Velikog, osobito ako se na umu ima da se u starijoj historiografiji Einharda smatralo jednim od autora / redaktora Godišnjakâ Franačkog Kraljevstva).
\end{abstract}

\section{Uvod}

U suvremenoj je historiografiji, u skladu s postmodernističkim i poststrukturalističkim zasadama, ${ }^{1}$ kritičko sagledavanje bliže prošlosti, jednako kao i davnih (predindustrijskih i prednacionalnih) povijesnih razdoblja, na svim interpretativnim razinama uistinu nemoguće ako se pritom neprestano na umu nema činjenica kako ono ovisi i o diskursu narativnog vrela koje se uzima za mjerodavno svjedočanstvo i o diskursu suvremenog istraživača koji gradi vlastiti narativ o prošloj stvarnosti. To nikako ne znači da se oba narativa postavljaju ili smiju postaviti na

\footnotetext{
Rad se zasniva na izlaganju sa znanstvenog skupa Bellvm Batonianvm MM. Rat protiv Batona: dvije tisuće godina koji se održavao 5. do 7. listopada 2009. godine na Filozofskom fakultetu Sveučilišta u Zagrebu.

1 Dobar pregled temeljnih odrednica postmodernističke teorije u historijskoj znanosti pruža BROWN 2005, napose 75-92 za poststrukturalističku teoriju.
} 
istu ravan, ali je neophodna svijest o tome da se interpretacija povijesnih procesa $\mathrm{i}$ zbivanjâ neizbježno napaja motrištem, stavovima i ciljevima koje slijedi i izražava i moderni autor. ${ }^{2}$ U vezi s navedenim potrebno je uzeti u obzir i tzv. kolonijalnu perspektivu koja je naročito vidljiva u imperijalnim povijesnim narativima, ${ }^{3}$ u ovom konkretnom slučaju rimskim i karolinškim. Kolonijalni diskurs nudi (pri)povijest iz očišta nadmoćnoga naspram onoga koji je podređen, oblikujući stvarnost koja odgovara takvom neravnopravnom odnosu i opravdava ga u ime viših nakana.

Predmetna poredbena studija zasniva se na glavnim latinskim vrelima koja bilježe podatke o ustanku Batonâ, odnosno o Ljudevitovu ustanku. Vrlo vrijedno svjedočanstvo za batonski rat pruža i grčki povjesnik Kasije Dion u dvjema knjigama (55. i 56) svoje djelomično očuvane Rimske povijesti iz 3. stoljeća, ${ }^{4}$ no to je djelo bilo nepoznato u zapadnoj Europi sve do 15. stoljeća kada je kardinal Besarion donio sa sobom u Italiju rukopis koji je sadržavao knjige od 34. do 60. (Codex Marcianus Graecus 395), ${ }^{5}$ pa shodno tomu nije niti moglo utjecati na pisce karolinške renesanse.

Vrela koja se razmatraju žanrovski su različita. Rimska povijest (Historia Romana) Veleja Paterkula pregledna je povjesnica od legendarnih prapočetaka Rima do piscu suvremenog doba (30. godine) u kojoj je najviše prostora posvećeno vremenu Cezara, Augusta i Tiberija. ${ }^{6}$ Životi Cezarâ (De vita Caesarum) Svetonija Trankvila zbirka je dvanaest rimskih carskih životopisa od Cezara do Domicijana, dovršena oko 121. godine, koja je ustanovila odrednice nove literarne vrste u rimskoj književnosti. ${ }^{7}$ Godišnjaci Franačkog Kraljevstva (Annales regni

2 Analizu različitih diskursa upravo u vezi s tretiranjem ustanka Batonâ u suvremenoj historiografiji nudi DŽINO 2009: 29-39.

3 Za kolonijalni diskurs i postkolonijalnu kritiku vidi LOOMBA 2000; INGHAM - WARREN 2003a: $1-15$.

4 Odabir relevantnih odlomaka u grčkom izvorniku i slovenskom prijevodu te povijesni komentar vidi kod ŠAŠEL KOS 1986: 166-191.

5 Besarion je svoju zbirku rukopisa koja je sadržavala i povjesnicu Kasija Diona darovao 1468. godine Mletačkoj Republici i ona je postala osnovom knjižnice Sv. Marka, Biblioteca Marciana (usp. ZORZI 2001: 479). Temeljit pregled rukopisne tradicije povjesnice Kasija Diona može se pronaći u izdanju francuskog prijevoda dviju njegovih knjiga, 50. i 51., Dion Cassius, Histoire Romaine. Livres 50 et 51, texte établi, traduit et annoté Marie-Laure Freyburger \& Jean-Michel Roddaz, [Collection des Universités de France, Budé], Pariz: Belles-Lettres, 1991. (pretisak 2002.).

6 Referentna su izdanja Velej Paterkul 1982, 1997, 1998. Hrvatski prijevod: Velej Paterkul 2006. Za monografsku studiju o Veleju Paterkulu usp. SCHMITZER 2000. Vidi i studije u COWAN 2011. Iscrpan povijesni komentar nudi WOODMAN 1977, 1983.

7 Referentna su izdanja Svetonije Trankvil 1993a, 1993b. Hrvatski prijevod: Svetonije Trankvil 1978. Najnovije kritičkoj izdanje je Svetonije Trankvil 2016. Za monografske studije o Svetoniju i njegovim carskim životopisima usp. MOUCHOVA 1968; CIZEK 1977; GUGEL 1977; BALDWIN 1983; WALLACE-HADRILL 1983; GASCOU 1984. Vidi i najnovije radove u POWER - GIBSON 2014. Također i studije u KASTER 2016, kao pratećem svesku uz izdanje Svetonije Trankvil 2016. 
Francorum), nekoć poznati i kao Annales Laurissenses maiores (Stariji lorschski godišnjaci), analističko su vrelo iz prve polovine 9 . stoljeća, a pokrivaju povijest rane karolinške države od 741. do 829. godine. ${ }^{8}$ Život cara Ludovika (Vita Hludowici imperatoris), djelo nepoznatog pisca nazvanog Astronom (Astronomus), biografija je franačkoga cara Ludovika I. Pobožnog nastala u prvoj polovini 9. stoljeća, koja u izlaganju slijedi kronološku logiku godišnjaka. ${ }^{9}$

Razlike u povijesnospisateljskoj vrsti nužno su odredile i fokus i izražajne mogućnosti svakoga pojedinoga vrela. Carske su biografije okrenute prvenstveno osobi, pa ona zbivanja koja po sudu pisca ne služe karakterizaciji glavnoga junaka niti pobliže osvjetljavaju njegovu ličnost i djelatnost odnosno njegovo doba imaju samo perifernu važnost i ne dobivaju naročitu pozornost. Godišnjacima su kao i kronikama nametnuta ograničenja samom formom jer je naglasak na konciznosti i vremenski susljednom redanju događaja, iako sadržani podaci znaju biti raznoliki. Povjesnica je najopsežnija historiografska vrsta koja potencijalno može biti i podatkovno najizdašnija, svakako pod preduvjetom da se zanimanje njezina autora poklapa s interesom suvremenih istraživača.

Svetonije Trankvil se ustanka Batonâ izravno dotaknuo samo u životopisu cara Tiberija (Vita Tiberi), u šesnaestom poglavlju (16.1-2), dok se u Augustovu životopisu (Vita Divi Augusti) uzgred spominje rat u Panoniji, odnosno osvajanje Panonije i Dalmacije s čitavim Ilirikom $(20 ; 21.1)$. Velej Paterkul je batonskom ratu posvetio mnogo veću pozornost pa se njegovim panonskim odsječkom bavi u pet poglavlja (2.110-114), a dalmatinskim odsječkom u dva poglavlja (2.115-116). Godišnjaci Franačkog Kraljevstva (ARF) glavno su vrelo za ustanak donjopanonskog kneza Ljudevita, o kojemu donose vijesti pod godinama 818, 819, 820., 821., 822. i 823. O ovom su prikazu zavisni podaci, jednim dijelom čak i obogaćeni, koji se mogu pronaći u Životu cara Ludovika. O knezu Ljudevitu i ratu protiv njega anonimni životopisac pripovijeda u šest poglavlja (31-36).

\section{Batonski rat i Ljudevitov rat}

Dobro je poznata činjenica kako je tzv. karolinška renesansa - sintagma potječe iz prve polovine 19. stoljeća $^{10}$ - intelektualno i ideološko nadahnuće našla u rimskoj antici. Kršćanska je Crkva u tomu odigrala ključnu ulogu posrednika, prenijevši Karolinzima rimske carske tradicije i ponudivši im plodotvorne obrasce

8 Referentno je izdanje $A R F$ 1895. Najvažnije su studije ADAMS 1977: 257-282; McKITTERICK 1997a: 101-129; McKITTERICK 2008: 27-49; COLLINS 1998: 191-213; EGGERT 2001: 122-134.

9 Referentno je izdanje Život cara Ludovika 1995. Najvažnije su studije BUCHNER 1940: 1445; TREMP 1991.

10 McKITTERICK 1977: xvi; TEEUWEN 2015, 23. 
da ustanove i objave vodeću poziciju koju nisu zauzeli samo u franačkoj državi nego i na kršćanskome Zapadu. Štoviše, Crkva je organizacijskom strukturom i monopolom na obrazovanje osigurala i provedbenu potporu u osnaživanju i širenju nove karolinške poruke oslonjene na rimsku carsku baštinu. ${ }^{11}$

Oslonac na rimsku literaturu jedna je od pojavnosti usvojene carske ideologije, što je nužno utjecalo kako na književnu, tako i na historiografsku produkciju karolinškoga doba. Kako bi se ojačala ta kulturna i ideološka osnovica, crkvena središta dobila su u zadatak prikupljati djela i umnažati rukopise važne napose za kršćansku učenost, već prema okružnici Karla Velikog De litteris colendis iz 784./785. godine i kartularu Admonitio generalis iz 789. godine. Pojedina crkvena središta uključena u te opće obrazovne napore, poput Lorscha, Corbiea, Fulde i Fleuryja, imala su u svojim knjižničnim fondovima i znatan broj djela poganskih klasičnih autora. ${ }^{12}$ Drugim riječima, samostanskim su prepisivačima i učenim ljudima onoga vremena na raspolaganju stajala i djela rimskih povjesnika koja, iz današnje perspektive, donose dragocjene podatke za ustanak Batonâ: Rimska povijest Veleja Paterkula i Životi cezarâ Svetonija Trankvila. Poznato je da je Einhard (Eginhard), koji je pripadao karolinškom dvorskom krugu i najužim suradnicima Karla Velikog, imao jedan rukopis povjesnice Veleja Paterkula, nastao u 8. stoljeću u Franačkoj (možda je on i zaslužan za izradu prijepisa u samostanu Murbach koji je u 16. stoljeću otkrio Beatus Rhenanus), a i svoj je Život Karla Velikog oblikovao po uzoru na Svetonijev životopis Augusta iz spomenute zbirke carskih biografija. ${ }^{13}$ Napokon, u karolinškome dvorskom krugu nastala su i najiscrpnija suvremena franačka vrela za ustanak donjopanonskog kneza Ljudevita, Godišnjaci Franačkog Kraljevstva i Život cara Ludovika.

Na prvi pogled najočitija poveznica između batonskoga rata i rata protiv donjopanonskog kneza Ljudevita, koje razdvaja punih osam stoljeća, bili bi njihovi nazivi, razvidno personalizirani: bellum Batonianum i bellum Liudewiticum. No sintagma bellum Batonianum poznata je samo iz natpisa (CIL V 3346), a ne iz literarnih rimskih vrela: tek Velej Paterkul rat naziva bellum Pannonicum (2.104.1, 2.117,1, pored 2.96.2). Čini se stoga da su nadahnuće za ime franački pisci Godišnjaka Fra-

11 MORELAND 2001: 402. O karolinškodobnoj aproprijaciji povijesnih djela iz rimskoga vremena vidi POHL 2015, 15-33. O transformaciji rimske prošlosti u kršćanskome kontekstu ranoga srednjovjekovlja usp. McKITTERICK 2004a; McKITTERICK 2015, 225-244.

12 BROWN 1997: 35; COLLINS 1998: 205; uz REYNOLDS - WILSON 1991, 95-102; McKITTERICK 1994: 100-104. Vidi i SIKIRIĆ 1992: 41. O karolinškom odnosu prema klasičnim autorima te postupcima i tehnikama uporabe i kritike klasičnih tekstova vidi napose TEEUWEN 2015, 23-50.

13 Za povjesnicu Veleja Paterkula: REYNOLDS 1984a: 431-433; BISCHOFF 1994: 148; uz BACHRACH 2001: 241, bilj. 49. O Svetoniju u kontekstu karolinškog 9. stoljeća vidi INNES 1997, posebno 267-270 za međuodnos Einharda i Svetonija. O tome također usp. i SIKIRIĆ 1992: 42-43. Hrvatski prijevod Einhardova Života Karla Velikog: Einhard 1992. 
načkog Kraljevstva našli u Florovu Izvatku iz rimske povijesti (Epitomae de Titi Livio bellorum omnium annorum DCC), ${ }^{14}$ gdje se navodi više tako personaliziranih ratova (bellum Mithridaticum, bellum Spartacium, bellum Sertorianum, bellum Catilinae), a upravo u Godišnjacima Franačkog Kraljevstva detektirane su stilske posudbe od rimskih pisaca Livija, Tacita, Cezara i Flora. ${ }^{15}$ Mogući je stariji uzor bio i Gaj Salustije Krisp sa svojim Jugurtinim ratom (Bellum Iugurthinum), jer je interes za Salustija u karolinško doba također doživio procvat. ${ }^{16}$ Da su kojim slučajem radije odabrali naziv po oblasti, mogli su se ugledati i u Galski rat (Bellum Gallicum) Gaja Julija Cezara, ali mnogo manje za nastavke njegova Građanskog rata (De bello civili) koje su sastavili nepoznati autori (Bellum Africum, Bellum Alexandrinum, Bellum Hispaniense) kao integralnih dijelova tzv. cezarovskog korpusa, budući da se čini kako su srednjovjekovni pisci uglavnom poznavali tek Galski rat. ${ }^{17}$

$\mathrm{U}$ odabiru pojmova kojim opisuju batonski rat rimski su pisci mnogo dramatičniji: za Veleja Paterkula to je bio bellum magnum atroxque, ,,velik i grozovit rat" (2.96.2) i da je tantus huius belli metus fuit, ut stabilem illum et firmatum tantorum bellorum experientia Caesaris Augusti animum quateret atque terreret, „bio toliki strah od tog rata da je onu postojanu i iskustvom tolikih ratova prekaljenu srčanost Cezara Augusta uzdrmao i zastrašio“ (2.110.6) - reći će on da je to bio i bellum maximum, ,presilan rat" (2.115.4), ali je to ponajprije povezao $\mathrm{s}$ „dalmatinskim ratom“ (bellum Delmaticum, 2.115.1). Na Velejev se stav izravno nadovezuje Svetonije svojim [bellum] ... gravissimum omnium externorum bellorum post Punica, ,najteži od svih izvanjskih ratova poslije punskih (Tib. 16.1). ${ }^{18}$

Franački izvori su u ocjeni rata protiv Ljudevita mnogo suzdržaniji. U njima se rabe i izrazi koji umanjuju važnost i opasnost sukoba opisujući ga kao pobunu (carmula, rebellio: $A R F$, a. 819$),{ }^{19}$ a tek u kasnijem dijelu prikaza nedvojbeno se

14 Referentna su izdanja Flor 1896, 1967. Hrvatski prijevod: Flor 2005. Glavne su studije DEN BOER 1972: 1-18; ALONSO-NUÑEZ 1983.

15 COLLINS 1998: 204-205; BULLOUGH 2004: 360. Zna se da je samostan u Lorschu imao rukopis Florova djela i da se njime koristio Einhard (MARSHALL 1984: 164-166; uz COLLINS 1998: 205; BACHRACH 2001: 241, bilj. 49).

16 Usp. BROWN - HASKINS - KASTER 2003: 192-193; McKITTERICK 2004b: 41. Također i REYNOLDS - WILSON 1991: 98, 101. O korištenju Salustija u srednjem vijeku vidi SMALLEY 1971. Referentna izdanja: Salustije 1957, 1991. Hrvatski prijevod: Salustije 1998.

17 Za Bellum Gallicum usp. McKITTERICK 2004b: 41, 193-194, 203; REYNOLDS - WILSON 1991: 98, 100. Detaljno za rukopisnu tradiciju De bello civili vidi BROWN 1972, 42-65; te, najnovije, ali sumarno DAMON 2015, 10-15. O tome da su srednjovjekovni pisci poznavali samo Galski rat: ALBRECHT 1997: 425.

18 Prijevodi izvornih odlomaka su autorovi, ali je posegnuto za postojećim hrvatskim prijevodima, gdje je to bilo moguće (Svetonije Trankvil 1978; Velej Paterkul 2006), dok su odstupanja, ako ih ima, stilskog karaktera.

19 Izraz carmula koristi se i u Emeramskim godišnjacima starijim (a. 819), a u Fuldskim godišnjacima (a. 819) kaže se da se Ljudevit pobunio (contra Liudewitum... rebellantem), što ponavljaju i Saintomerski godišnjaci (a. 819). 
govori o ratu ( $A R F$, a. 821, 822: bellum Liudewiticum u dva navrata). Doduše, da je Ljudevitov ustanak značio popriličnu ugrozu za franačke pozicije na jugoistoku njihova vladavinskog područja, zorno pokazuje pozornost koju je dobio u vrelima. ${ }^{20}$ Naznaku toga pruža Život cara Ludovika (32) gdje se donosi podatak kako je car radosno saslušao (letus audivit) vijest o tomu da je dalmatinsko-liburnski knez Borna nanio Ljudevitu velike gubitke u ljudstvu i opremi te ga prisilio na povlačenje iz svoje oblasti u koju je ovaj provalio.

Za franačke izvore rat protiv Ljudevita je strogo personaliziran: oni govore o Ljudevitovu odmetništvu (Liudewiti defectio, $A R F$, a. 820) i otvorenoj izdaji (Liudeviti operta perduellio, Život cara Ludovika, 32). Nasuprot tome, rimski izvori bilježe „odmetništvo Ilirika“ (defectio Illyrici, Suet. Tib. 16.2) - ovdje se bjelodano opaža i srodnost izričaja između Godišnjaka Franačkog Kraljevstva i Svetonijeva Tiberijeva životopisa - odnosno, u povjesnici Veleja Paterkula, spominju „panonski rat“ (2.96.2) i „cijelu Panoniju“ (universa Pannonia, 2.110.2) koja grabi oružje.

U vezi s uzrocima rata uočava se veća sličnost. Velej Paterkul ističe da je Panonija bila insolens longae pacis bonis, adulta viribus, „bahata zbog blagodati dugog mira, a jaka zbog svojih snaga“"(2.110.2), a franačka pak vrela naglašavaju Ljudevitovu oholost i drskost (ARF, a. 819: superbia, Život cara Ludovika, 32: arrogantia), njegovo vjerolomstvo (ARF, a. 821: perfidia, Život cara Ludovika, 32: perfidia), navode da je spremao prevrat (qui res novas moliens, $A R F$, a. 818) i da je čak preko svojih poslanika pokušao diktirati uvjete mira $(A R F$, a. $819, \check{Z}$ ivot cara Ludovika, 32), te ga uzdižu i u uzurpatora (tyrannus, Život cara Ludovika, 36), čime se krivnja za sukob nedvojbeno prebacuje na protivničku stranu. Ovo je osnaženo bilješkom da je Ljudevit, nakon što je pobjegao iz Panonije i sklonio se u Dalmaciji, uputio poslanike Ludoviku s obećanjem da će se predati, poručivši da je zastranio (errasse se dixit, Život cara Ludovika 35). ${ }^{21}$ Doduše, Godišnjaci Franačkog Kraljevstva kazuju i da se Ljudevit pritužio na „okrutnost i bahatost“ (crudelitas atque insolentia) furlanskoga markgrofa Kadolaha $(A R F$, a. 818), a

$\overline{20}$ U 11. stoljeću je rat protiv Ljudevita zabilježio u svojoj Kronici i Herman Kontrakt (iz Reichenaua) pod trima godinama: Contra Liudewitum Sclavum in Pannonia rebellantem exercitus de Italia missus, „Protiv Slavena Ljudevita koji se pobunio u Panoniji upućena je vojska iz Italije“ (Herman Kontrakt 1844, a. 819); Tres exercitus de Francia, Saxonia atque Italia in Pannoniam contra Liudiwitum missi, „Tri vojske, iz Franačke, Saske i Italije, upućene su u Panoniju protiv Ljudevita“ (ibidem, a. 820); Liudiwitus in Dalmatia ab hospitibus suis interficitur, „Ljudevita su ubili njegovi domaćini u Dalmaciji““ (ibidem, a. 823). Vrijedi istaknuti da su pod godinom 819. i 820. vijesti o Ljudevitu na prvom mjestu u navodu, a pod godinom 823. na drugom mjestu. Petar Bibliotekar je potkraj 9. stoljeća u svojoj Pokraćenoj povijesti Franaka (Historia Francorum abbreviata) također smatrao vrijednim navesti da je Liudevithus dolo Alvidemilii, avunculi Bornae duci Dalmatarum, interitur, „Ljudevit je ubijen spletkom Alvidemilija (= Ljudemisla), ujaka kneza Dalmatinaca Borne“ (1826, a. 824).

${ }^{21} \mathrm{U}$ Životu cara Ludovika je dopunjena vijest iz $A R F, a$. 822, gdje nema takvog Ljudevitova priznanja. 
u Životu cara Ludovika stoji da se pritužba odnosila na ,njegovu nepodnošljivu nečovječnost“" (inmanitas illius inportabilis, 31), ali se nadodaje kako je sve to bilo „lažno kao što se poslije otkrilo“ (falso, ut post patuit, 31). Ovo kao da ponešto podsjeća na glasovitu rečenicu koju donosi Dion Kasije - doduše, kako je već istaknuto, nepoznat franačkim piscima - da je ustanički vođa Baton (dezitijatski) za izbijanje ustanka okrivio Rimljane, ,jer za čuvare svojih stada ne šaljete ni pse ni pastire nego vukove“ (56.16.3). U svakom slučaju, i rimski i franački pisci pružaju uobičajen imperijalno- kolonijalni pogled iz kojega izviru stereotipi o onima neuljuđenima („,barbarima“) koji se teško privikavaju na civilizatorsko djelovanje nadmoćnije kulture. ${ }^{22}$

Dok Franci krajnje negativno oslikavaju vođu ustanka južnopanonskih Slavena i općenito svoje protivnike - kad se u Godišnjacima Franačkog Kraljevstva opisuje „panonski pohod“ (expeditio Pannonica) u ljeto 821. godine, navodi se da su tri franačke vojske naizmjence poharale polja vjerolomnikâ $(A R F$, a. 821: agri perfidorum) - dotle je Velej Paterkul mnogo naklonjeniji ustaničkim ratovodstvenim kapacitetima, pa tako hvali njihovu bojovnost i ratnu odlučnost (2.110.5: natio tam mature consilio belli bellum iunxit ac decreta patravit), vojničku srčanost (ferox iuventus, 2.114.4) te ratničku ćud i vještinu (2.115.4: ingeniorum ferocia, mira etiam pugnandi scientia) - ovo se, doduše, odnosi na dalmatinske ustanike - a Svetonije piše o premoćnom neprijatelju (praevalens hostis), ne krateći se jasno naznačiti da je rat bio povezan s velikim poteškoćama (magnae omnium rerum difficultates, Tib., 16.1). No stoga su i Velej Paterkul i Svetonije opasnom neprijatelju i tegobama u vođenju rata suprotstavili još veći trijumf rimskog oružja: Velej Paterkul lakonski kaže victor ... exercitus (2.114.5). Franačka vrela naglašavaju da im se Ljudevit nije izravno suprotstavio na bojnom polju (ARF, $a .820,821$, 822, Život cara Ludovika, 33, 35), a jedanput kad se sraz i dogodio, njegovu je četu, iako je bila nadmoćnija brojem, potukao kod rijeke Drave markgrof Baldrik (ARF, a. 819, Život cara Ludovika, 32). Drugačiju sliku rišu rimski izvori u vezi s batonskim ratom jer se ustanici u Panoniji nisu kratili sukobljavati s rimskim četama. Velej Paterkul će tako retorski iskićeno uzviknuti: Quas nos primo anno acies hostium vidimus!, „Koje li smo bojne redove neprijatelja vidjeli u prvoj godini!““ (2.111.4). Štoviše, potukli su i konjaničke postrojbe tračkoga kralja Remetalka i drugih saveznika, ali su rimski vojnici, u najvećoj stisci, unatoč nesmotrenosti svojih zapovjednika Aula Cecine Severa i Marka Plaucija Silvana, ipak izvojevali pobjedu (2.112.4-6). No ni takvi strašni protivnici, barbari, kaže Velej Paterkul, nisu se usudili sučeliti s Tiberijem bez obzira na svoju brojnost i snagu (2.112.3). Napokon, i Rimljani su imali parnjaka markgrofu Baldriku - namjesnik Ilirika

22 Za takav diskurs kod Veleja Paterkula u vezi s batonskim ratom usp. DŽINO - DOMIĆ KUNIĆ 2013, 173. O toposu civiliziranja barbara u rimskoj literaturi kasne Republike i ranoga Carstva vidi SCHERR 2015. 
Marko Valerije Mesala Mesalin porazio je u ljeto prve godine pobune višestruko nadmoćniju ustaničku vojsku (2.112.1-2).

Poteškoća nije bilo lišeno niti franačko vojevanje protiv Ljudevita: Godišnjaci Franačkog kraljevstva spominju neuspjeh prvog vojnog udara pod vodstvom markgrofa Kadolaha koji je ubrzo umro od groznice $(A R F, a .819)$ te snažan otpor ustanika u godinama 820 . i 821 . koji je onemogućavao franačko napredovanje $(A R F, a .820,821){ }^{23}$ pa čak i izbijanje bolesti među vojnicima zbog nezdrava podneblja i loše vode u močvarištima duž srednje Drave $(A R F, a .821),{ }^{24}$ a naglašava se i širenje osnovice ustanka na druge etničke zajednice, kako na zapadu tako i na istoku savsko-dravsko-dunavskoga međuriječja - Karniolce, Karantance, Timočane - što je dodatno ugrožavalo franačke pozicije $(A R F, a .819)$.

Slična logika u ratovodstvu priziva i slične izričaje: Ljudevit napada Dalmaciju i ferro et igni cuncta devastat, ,,sve ognjem i mačem pustoši“ ( $A R F, a .819)$, odnosno ferro quae animata erant perimens, inanimata vero igni contradens, ,željezom zatirući što bijaše živo, a neživo predajući ognju“ (Život cara Ludovika, 32), upravo kao što su se panonski pobunjenici osam stoljeća prije pobrinuli da omnia et in omnibus locis budu igni ferroque vastata, ,sve na svim mjestima opustošeno ognjem i mačem“ (Vell. Pat. 2.110.6). No takvu taktiku još bolje poznaju carstva: franačka vojska je u nekoliko navrata opustošila Ljudevitovu oblast $(A R F, a .820$ : ad devastandam eius regionem, totam pene regionem ferro et igni devastantes, a. 821: qui futura aestate perfidorum agros per vices vastarent, qui depopulata desertorum et Liudewito adhaerentium universa regione), ${ }^{25}$ dok su Rimljani u Dalmaciji - konkretno, Tiberijev dozapovjednik Marko Emilije Lepid - uništavali polja, palili kuće i sjekli ljude (Vell. Pat. 2.115.2: excisis agris, exustis aedificiis, caesis viris). Moguće je zapaziti još jednu sličnost u pojedinostima batonskog, odnosno Ljudevitova rata: dalmatinski pobunjenici mogli su se u otporu pouzdati u svoju planinska sjedišta (situs locorum ac montium) i naročito uzane gorske prijelaze (praecipue angustiis saltuum), kako svjedoči Velej Paterkul (2.115.4), dok se Ljudevit, prema Godišnjacima Franačkog Kraljevstva, oslanjao na utvrde na strmoj gori (castelli... in arduo monte, $A R F, a .820$ ) koje se trudio dodatno ojačati uz pomoć gradeškog (akvilejskog) patrijarha Fortunata, inače franačkog podanika $(A R F, a .821){ }^{26}$

23 Neuspjeh prvog vojnog udara spominje i Život cara Ludovika (c. 32), a to ponavljaju Fuldski godišnjaci (a. 819) i Herman Kontrakt (a. 819).

24 Ovaj podatak doslovce prepisuju Fuldski godišnjaci (a. 820).

25 To bilježe na dva mjesta i Život cara Ludovika (c. 33; 34) te jedanput Fuldski godišnjaci (a. 820), odnosno Herman Kontrakt (a. 820). I Tegan (9. stoljeće) je u Djelima cara Ludovika (Gesta Hludowici imperatoris) zapisao da je franačka vojska opustošila zemlju „Istočnih Slavena“ (orientales Sclavi), čiji se knez (dux) zvao Ljudevit, a kojega je natjerala u bijeg (c. 27), saževši četverogodišnji rat u jednu rečenicu.

26 Ljudevitov zaklon u utvrdi na uzvisini spominje i Život cara Ludovika (c. 33). 
Isticanje brojnosti četa u slamanju ustanaka ima i kod rimskih i kod franačkih pisaca funkciju dodatnog ilustriranja ozbiljnosti situacije, ali i uživanja u vlastitoj vojnoj moći. Velej Paterkul navodi deset legija, više od sedamdeset kohorti, četrnaest ala i više od deset tisuća veterana te velik broj dobrovoljaca, uz konjaništvo savezničkog kralja, sabranih na zbornom mjestu u Sisciji (2.113.1), ${ }^{27}$ Svetonije spominje petnaest legija i jednak broj pomoćnih četa (Tib., 16.1), a Godišnjaci Franačkog Kraljevstva sveukupno nabrajaju deset vojski koje su bile odaslane protiv Ljudevita, napose 821. godine kad su čete sabrane iz svih dijelova Franačkog Carstva, Saske, istočne Franačke, Alamanije, Bavarske i Italije. Velej Paterkul je zabilježio i brojnost pobunjenika: više od osamsto tisuća u Panoniji i Dalmaciji, od toga dvjesto tisuća uvježbanih pješaka i devet tisuća konjanika (2.110.3). Na daljnja dva mjesta ističe ustaničku brojčanu premoć: Mesalin se suočio s više od dvadeset tisuća neprijatelja (2.112.2), a općenito je bilo na tisuće ratnika s kojima su se Rimljani morali tući (2.114.4). Franačka vrela ništa ne kažu o ukupnom broju Ljudevitovih snaga, ali zato sa zadovoljstvom izvješćuju kako je knez Borna uništio tri tisuće njegovih vojnika i zaplijenio mu više od tristo konja $(A R F, a .819)$.

I u galeriji likova u ovim ratnim dramama mogu se iznaći sličnosti i razlike u ulogama. Ljudevit je postavljen sučelice dvojici Batona i Pinetu; Ludovik je, dakako, parnjak Augustu, ali i Tiberiju, budući da franački car, iako je daleko u središtu svoje države, mudro i smireno vuče poteze koji određuju tijek gušenja pobune; franački vojskovođa Kadolah stoji nasuprot rimskim zapovjednicima Aulu Cecini Severu i Marku Plauciju Silvanu, čiji je vojni uspjeh bio polovičan, dok se markgrofu Baldriku, koji je u jednoj čarki porazio Ljudevitovu vojsku, može preslika pronaći u uspješnom Marku Valeriju Mesali Mesalinu; napokon, dalmatinsko-liburnski knez Borna odgovara tračkom kralju Remetalku, ali je svoju ulogu odigrao mnogo uspješnije; jedino još Franci imaju izdajnika među svojim redovima, gradeškog (akvilejskog) patrijarha Fortunata. Na koncu, vrijedi istaknuti i još jednu podudarnost, u trajanju ratnog sukoba: oba su se rata vukla četiri godine, batonski, od 6. do 9. godine, a Ljudevitov od 819. do 822. godine.

I rimski i franački izvori oba ovdje razmatrana događaja, batonski, odnosno Ljudevitov rat, sagledavaju, svaki na svom vremenskom planu, iz očišta neporecivih vlastodržaca koji svojim gospodstvom jamče red i opći boljitak pa je i svaki pokušaj da se promijeni postojeće stanje udar na ispravan poredak stvari. Njihov je kolonijalni diskurs sasvim očigledan. Čak i kad naizgled ističu vrline

27 Analizu brojnosti rimskih i ustaničkih snaga kod Veleja Paterkula donosi DŽINO 2006, 145 159. 
svojih protivnika (redovito su to ratničke vrline) ili poteškoće s kojima je bilo povezano vojevanje protiv pobunjenika te početnu zabrinutost, čine to kako bi uveličali vlastiti uspjeh.

Na pripovjednoj razini, u oblikovanju narativa, vidljiva je ovisnost franačkih pisaca o rimskim literarnim uzorima, što se, u skladu sa žanrovskim ograničenjima, ogleda u uzajmljivanju sintagmi i koncepcijskih sklopova. Može li se pritom govoriti i o neposrednom osloncu u vezi s geopolitičkim obzirima (podudarnosti prostora zbivanja), teško je sa sigurnošću reći, ali ovdje provedena analiza ipak bi upućivala na to da su franački pisci toga svakako bili svjesni. Stroga personalizacija karolinškodobnoga rata u južnoj Panoniji - osim što je više odgovarala duhu vremena jer je riječ o vazalu koji je ustao protiv svojeg vrhovnika - po svoj prilici je i posljedica toga što bi općeniti spomen panonskog rata u ondašnjem kontekstu mogao čitatelje zavesti da pomisle kako je zahvaćeno bilo i područje sjeverno od Drave, čitav limes Pannonicus (ARF, a. 826). Svojevrstan je dug rimskim predlošcima i ovdje plaćen spomenom ,panonskog pohoda“. Sigurno je svakako da iz franačkih zapisa jasno proizlazi kako je Ljudevitov ustanak pojedinačno bio najpotresniji događaj u povijesti karolinške prevlasti na prostoru između Dunava i Jadrana, što je njihovim sastavljačima moralo biti samo dodatan poticaj da im pred očima kao literarni uzor i politička prethodnica iskrsne batonski ustanak koji su sami Rimljani okrstili najtežim svojim sukobom poslije punskih ratova.

Na kraju može se kazati da su epilog i pouka priče i rimskih i franačkih prikaza u osnovi, mutatis mutandis, istovjetni i odgovaraju ideološkim postavkama oba carstva: u oba slučaju su ustanici poraženi, njihovi su vođe opravdano kažnjeni, a carstva su se domogla zasluženih trijumfa. Manje jedva da se moglo (ili smjelo) očekivati. 
Bibliografija

\section{Kratice}

CIL: Corpus inscriptionum Latinarum

MGH: Monumenta Germaniae historica

\section{Izdanja izvora}

ARF 1895. Annales regni Francorum inde ab a. 741 usque ad a. 829, qui dicuntur Annales Laurissenses maiores et Einhardi. Recognovit Friedrich Kurze, [MGH Scriptores rerum Germanicarum 6]. Hannover: Hahn, 1895. (pretisak 1950).

Einhard 1992. Einhard, Život Karla Velikog. Prevela Zvjezdana Sikirić. Uvodne tekstove i komentar napisali Lovorka Čoralić, Ivo Goldstein i Zvjezdana Sikirić, [Biblioteka Latina \& Graeca 34]. Zagreb: Latina et Graeca, 1992.

Emeramski godišnjaci stariji 1826. Annales sancti Emmerammi Ratisponensis maiores. Edidit Georg Heinrich Pertz, [MGH Scriptores 1]. Hannover: Hahn, 1826., 92-93.

Flor 1896. L. Annaei Flori Epitomae libri II et P. Annii Flori fragmentvm De Vergilio oratore an poeta. Edidit Otto Rosbach. Leipzig: Teubner, 1896.

Flor 1967. Lucius Annaeus Florus, Oeuvres I-II. Tableau de l'Histoire du peuple romain, de Romulus à Auguste. Texte établi et traduit par Paul Jar, [Collection des universités de France, Budé]. Pariz: Les Belles Lettres, 1967.

Flor 2006. Lucije Anej Flor, Dvije knjige izvadaka iz Tita Livija o svim ratovima u sedam stotina godina. Preveo i priredio Josip Miklić, [Biblioteka Latina \& Graeca 53]. Zagreb: Izdanja Antibarbarus, 2006.

Fuldski godišnjaci 1891. Annales Fuldenses I (auctore Einhardo). U Annales Fuldenses sive Annales regni Francorum orientalis. Recognovit Friedrich Kurze, [MGH Scriptores rerum Germanicarum 7]. Hannover: Hahn, 1891., 1-28.

Herman Kontrakt 1844. Herimanni Augiensis Chronicon de sex aetatibus mundi. Edidit Georg Heinrich Pertz, [MGH Scriptores 5]. Hannover: Hahn, 1844., 67-133.

Petar Bibliotekar 1826. Petri Bibliothecarii Historia Francorum abbreviata. Edidit Georg Heinrich Pertz, [MGH Scriptores 1]. Hannover: Hahn, 1826., 416-418.

Saintomerski godišnjaci 1881. Annales Sithienses. U Supplementa tomorum I-XII, pars I. Edidit Georg Waitz, [MGH Scriptores 13]. Hannover: Hahn, 1881., 34-38.

Salustije 1957. C. Sallustius Crispus, Catilina. Iugurtha. Fragmenta ampliora. Post Axel Wilhelm Ahlberg eddidit Alfons Kurfess, [Bibliotheca scriptorum Graecorum et Romanorum Teubneriana 1763]. Leipzig: Teubner, ${ }^{3} 1957$.

Salustije 1991. C. Sallustius Crispus, Catilina; Iugurtha; Historiarum Fragmenta Selecta; Appendix Sallustiana. Recognovit brevique adnotatione critica instruxit Leighton D. Reynolds, [Oxford Classical Texts]. Oxford 1991. ('1998).

Salustije 1998. Gaj Salustije Krisp, Djela. Preveo Josip Miklić. Zagreb: Matica hrvatska, 1998. 
Svetonije Trankvil 1993a. C. Svetonius Tranqvillus Opera I. De vita Caesarum libri VIII. Recensuit Maximilian Ihm, [Bibliotheca scriptorum Graecorum et Romanorum Teubneriana 1827]. München-Leipzig: K. G. Saur, ${ }^{3} 1993$.

Svetonije Trankvil 1993b. Suétone, Vie des douze césars I-III. Texte établi et traduit par Henri Ailloud, [Collection des universités de France, Budé]. Pariz: Les Belles Lettres, ${ }^{3} 1993$.

Svetonije Trankvil 2016. C. Suetoni Tranquilli 'De vita Caesarum libri VIII' et 'De grammaticis et rhetoribus libri'. Recognovit brevique adnotatione critica instruxit Robert A. Kaster, [Oxford classical texts]. Oxford-New York: Oxford University Press, 2016., 1-422.

Svetonije Trankvil 1978. Gaj Svetonije Trankvil, Dvanaest rimskih careva. Preveo, uvod i bolješke napisao Stjepan Hosu. Zagreb: Naprijed, ${ }^{2} 1978$.

Tegan 1995. Thegan, Die Taten Kaiser Ludwigs (Gesta Hludowici imperatoris). Astronomus, Das Leben Kaiser Ludwigs (Vita Hludowici imperatoris). Herausgegeben und übersetzt von Ernst Tremp, [MGH Scriptores rerum Germanicarum 64]. Hannover: Hahnsche Buchhandlung, 1995.: 167-277.

Velej Paterkul 1982. Velleius Patercullus, Histoire romaine I-II. Texte établi, traduit et annoté par Joseph Hellegouarc'h, [Collection des Universités de France, Budé]. Pariz: Belles-Lettres, 1982

Velej Paterkul 1997. Velleius Paterculus, Ad M. Vinicium consulem libri duo. Curavit adnotavitque Maria Elefante, [Bibliotheca Weidmanniana 3]. Zürich: Hildesheim, 1997.

Velej Paterkul 1998. Vellei Paterculi Historiarum ad M. Vinicium consulem libri duo. Recognovit William Smith Watt, [Bibliotheca scriptorum Graecorum et Romanorum Teubneriana 1873]. Stuttgart: Teubner, ${ }^{2} 1998$.

Velej Paterkul 2006. Gaj Velej Paterkul, Rimska povijest. Preveo i priredio Josip Miklić, [Biblioteka Latina \& Graeca 57]. Zagreb: Izdanja Antibarbarus, 2006.

Život cara Ludovika 1995. Thegan, Die Taten Kaiser Ludwigs (Gesta Hludowici imperatoris). Astronomus, Das Leben Kaiser Ludwigs (Vita Hludowici imperatoris). Herausgegeben und übersetzt von Ernst Tremp, [MGH Scriptores rerum Germanicarum 64]. Hannover: Hahnsche Buchhandlung, 1995.: 279-555.

\section{Literatura}

ADAMS, James Noel. 1977. The Vocabulary of the Annales Regni Francorum. Glotta 55: 257-282.

ALBRECHT, Michael von. 1997. A History of Roman Literature. From Livius Andronicus to Boethius, with special regard to its influence on world literature. Volume 1. LeidenNew York-Köln: E. J. Brill.

ALONSO-NUÑEZ, Jose Miguel. 1983. Die politische und soziale Ideologie des Geschichtsschreibers Florus. Bonn: R. Habelt.

BACHRACH, Bernard S. 2002. Charlemagne's Military Responsibilities am Vorabend der Kaiserkrönung. U Am Vorabend der Kaiserkrönung. Das Epos ,, Karolus Magnus et Leo papa " und der Papstbesuch in Paderborn 799, uredili Peter Godman, Jörg Jarnut, Peter Johanek, 231-255. Berlin: Akademie Verlag. 
BALDWIN, Barry. 1983. Suetonius: Biographer of the Caesars. Amsterdam: A. M. Hakkert.

BISCHOFF, Bernard. 1994. Manuscripts and libraries in the age of Charlemagne. Preveo i priredio Michael Gorman, [Cambridge studies in palaeography and codicology 1]. Cambridge: Cambridge University Press (2007).

DEN BOER, Willem. 1972. Some Minor Roman Historians. Leiden: Brill.

BROWN, Callum G. 2005. Postmodernism for Historians. Harlow-London: PearsonLongman.

BROWN, Giles. 1997. Introduction: the Carolingian Renaissance. U McKITTERICK 1997b: 1-51.

BROWN, Virginia. 1972. The textual transmission of Caesar's Civil war, [Mnemosyne, bibliotheca classica Batava. Supplementum 23]. Leiden: Brill.

BROWN, Virginia, James HANKINS, Robert A. KASTER, ur. 2003. Catalogus translationum et commentariourm: Mediaeval and Renaissance Latin Translations and Commentaries. Annotated Lists and Guides. Volume VIII. Washington: The Catholic University of America Press, 2003.

BUCHNER, Max. 1940. Entstehungszeit und Verfasser der „Vita Hludowici“ des „Astronomus“. Historisches Jahrbuch 60: 14-45.

BULLOUGH, Donald A. 2004. Charlemagne's court library revisited. Early Medieval Europe 12: 339-363.

CIZEK, Eugen. 1977. Structures et idéologie dans la Vie des douze Césars de Suétone. Bukurešt-Pariz: Editura Academiei-Les Belles Lettres.

COLLINS, Roger. 1998. 'Reviser' Revisited: Another Look at the Alternative Version of the Annales Regni Francorum. U After Rome's Fall. Narrators and Sources of Early Medieval History. Essays presented to Walter Goffart, edited by Alexander Callander Murray, 191-213. Toronto-Buffalo-London: University of Toronto Press.

COWAN, Eleanor, ur. 2011. Velleius Paterculus: Making History. Swansea: Classical Press of Wales.

DAMON, Cynthia. 2015. Studies on the Text of Caesar's Bellum civile. Oxford: Oxford University Press.

DŽINO, Danijel. 2006. Velleius Paterculus and the Pannonii: Making up the numbers. Godišnjak Akademije nauka i umjetnosti Bosne i Hercegovine XXXV, Centar za balkanološka ispitivanja 33: 145-159.

DŽINO, Danijel. 2009. The Bellum Batonianum in contemporary historiographical narratives in a search for the post-modern Bato the Daesitiate. Arheološki radovi $i$ rasprave 16: $29-45$.

DŽINO, Danijel, Alka DOMIĆ KUNIĆ. 2013. Rimski ratovi u Iliriku. Povijesni antinarativ, [Biblioteka Lucius 7]. Zagreb: Školska knjiga, 2013.

EGGERT, Wolfgang. 2001. Zu Inhalt, Form und politischer Terminologie der 'Fränkischen Reichsannalen'. U Karl der Große und das Erbe der Kulturen, herausgegeben von Franz-Reiner Erkens, 122-134. Berlin: Akademie Verlag. 
GANTNER, Clemens, Rosamond McKITTERICK, Sven MEEDER, ur. 2015. The Resources of the Past in Early Medieval Europe. Cambridge: Cambridge University Press.

GASCOU, Jacques. 1984. Suétone historien, [Bibliothèque des Écoles françaises d'Athènes et de Rome 255]. Rim: École française de Rome.

GUGEL, Helmut. 1977. Studien zur biographischen Technik Suetons. Aus dem Nachlaß herausgegeben von Karl Vretska, [Wiener Studien, Beiheft 7]. Beč: H. Böhlaus.

INGHAM, Patricia Clare, Michelle R. Warren, ur. 2003. Postcolonial Moves: Medieval through Modern. New York-Houndsmills, Basingstoke: Palgrave Macmillan, 2003.

INGHAM, Patricia Clare, Michelle R. WARREN. 2003a. Introduction: Postcolonial Modernity and the Rest of History. U INGHAM - WARREN 2003: 1-15.

INNES, Matthew. The Classical Tradition in the Carolingian Renaissance: Ninth-Century Encounters with Suetonius. International Journal of the Classical Tradition 3: 265-282.

KASTER, Robert A. 2016. Studies on the Text of Suetonius ' De uita Caesarum'. OxfordNew York: Oxford University Press.

LOOMBA, Ania. 2000. Colonialism / Postcolonialism. London-New York: Routledge.

MARSHALL, Peter K. 1984. Florus. U REYNOLDS 1984: 164-166.

MORELAND, John. 2001. The Carolingian empire: Rome reborn. U Empires: perspectives from archeology and history, edited by Susan E. Alcock, Terence N. D'Altroy, Kathleen D. Morrisson, Carla M. Sinopoli, 392-418. Cambridge: Cambridge University Press.

MCKITTERICK, Rosamond. 1977. The Frankish church and the Carolingian reforms, 789-895, [Royal Historical Society Studies in History]. London: The Lincoln Record Society.

MCKITTERICK, Rosamond Deborah. 1994. McKitterick. The audience for Latin historiography in the early Middle Ages: text transmission and manuscript dissemination. U Historiographie im frühen Mittelalter, herausgegeben von Anton Scharer, Georg Scheilbelreiter, 96-114, [Veröffentlichungen des Instituts für Östereichische Geischitsforschung 32]. Beč-München: R. Oldenbourg Verlag.

McKITTERICK, Rosamond Deborah. 1997a. Constructing the Past in the Early Middle Ages: The Case of the Royal Frankish Annals. Transactions of the Royal Historical Society 6 ser., 7: 101-129.

MCKITTERICK, Rosamond, ur. 1997b. Carolingian Culture: emulation and innovation. Cambridge: Cambridge University Press.

MCKITTERICK, Rosamond, 2004a. Perceptions of the Past in the Early Middle Ages, [The Conway Lectures in Medieval Studies 2004]. Notre Dame, Indiana: University of Notre Dame Press.

McKITTERICK, Rosamond, 2004b. History and Memory in the Carolingian World. Cambridge: Cambridge University Press.

MCKITTERICK, Rosamond Deborah. 2008. Charlemagne. The Formation of a European Identity. Cambridge: Cambridge University Press.

MCKITTERICK, Rosamond Deborah. 2015. Transformations of the Roman past and Roman identity in the early Middle Ages. U GANTNER - McKITTERICK - MEEDER $2015,225-244$. 
MOUCHOVA, Bohumila. 1968. Studie zu Kaiserbiographien Suetons, [Acta Universitatis Carolinae. Philosophica et Historica. Monographia 22]. Prag: Universita Karlova.

POHL, Walterr. 2015. Creating cultural resources for Carolingian rule: historians of the Christian empire. U GANTNER-McKITTERICK-MEEDER 2015, 15-33.

POWER, Tristan, Roy K. GIBSON, ur. 2014. Suetonius, the Biographer: Studies in Roman Lives. Oxford-New York: Oxford University Press.

REYNOLDS, Leighton Durham, ur. 1984. Texts and Transmission: A Survey of the Latin Classics. London-New York: Clarendon Press-Oxford University Press.

REYNOLDS, Leighton Durham. 1984a. Velleius Paterculus. U REYNOLDS 1984: 431-433.

REYNOLDS, Leighton Durham, Nigel Guy WILSON. 1991. Scribes and Scholars: A Guide to the Transmission of Greek and Latin Literature. Oxford: Clarendon Press (3. izdanje).

SCHERR, Jonas. 2015. Die Zivilisierung der Barbaren: Literarischer Topos und politisches Ethos von der späten Republik bis ins dritte Jahrhundert nach Christus. Disseration, Universität Innsbruck.

SCHMITZER, Ulrich. 2000. Velleius Paterculus und das Interesse an der Geschichte im Zeitalter des Tiberius, [Bibliothek der klassischen Altertumswissenschaften, Reihe 2, N. F., 107]. Heidelberg: Winter.

SIKIRIĆ, Zvjezdana. 1992. Einhardov „Život Karla Velikog“. U Einhard 1992: 37-45.

SMALLEY, Beryl. 1971: Sallust in the Middle Ages. U Classical influences on European culture A.D. 500-1500: proceedings of an international conference held at King's College, Cambridge, April 1969, edited by Robert Ralph Bolgar, 165-176. Cambridge: University Press.

ŠA ŠEL KOS, Marjeta. 1986. Zgodovinska podoba prostora med Akvilejo, Jadranom in Sirmijem pri Kasiju Dionu in Herodijanu. Ljubljana: Slovenska akademija znanosti in umetnosti.

TEEUWEN, Mariken. 2015. Carolingian Scholarship on Classical Authors: Practices of Reading and Writing. U Manuscripts of the Latin Classics 800-1200: Studies in Medieval and Renaissance Book Culture, edited by Erik Kwakkel, 23-52. Leiden: Leiden University Press.

TREMP, Ernst. 1991. Die Überlieferung der Vita Hludowici imperatoris des Astronomus, [MGH, Studien und Texte 1]. Hannover: Hahnsche Buchhandlung.

WALLACE-HADRILL, Andrew. 1983. Suetonius: the Scholar and his Caesars, [Classical Life and Letters]. London: Duckworth (London: Bristol Classical Press, ${ }^{2} 1995$ ).

WOODMAN, Anthony John. 1977. Velleius Paterculus. The Tiberian Narrative (2.94131), [Cambridge Classical Texts and Commentaries 19]. Cambridge: Cambridge University Press ( $\left.{ }^{2} 2004\right)$.

WOODMAN, Anthony John. 1983. Velleius Paterculus. The Caesarian and Augustan Narrative (2.41-93), [Cambridge Classical Texts and Commentaries 25]. Cambridge: Cambridge University Press ( $\left.{ }^{2} 2004\right)$.

ZORZI, Marino. 2001. National Libraries of Italy. U International Dictionary of Library Histories I, edited by David H. Stam, 472-481. Chicago-London: Fitzroy Dearborn Publishers. 


\section{Bellum Batonianum and Bellum Liudewiticum: analogies and differences}

The paper offers an analyzes of the parallels between the so-called War of the Batos (Bellum Batonianum) and the war against the duke of Lower Pannonia, Liudewit (Bellum Liedewiticum) based on ancient and early medieval written sources. Particular attention is paid to the depictions of situations and expressions used by authors in describing both wars, in order to detect the historiographical and ideological pattern and interdependence of the narratives. The differences resulting from various historiographical genres and ideological needs are also observed. Finally, the practical presentations of both wars are compared according to the available source material. The basis for comparison are accounts found in the Annales regni Francorum and the Vita Hludowici imperatoris, which were compiled in the first half of the 9th century, and are the most comprehensive sources for the uprising of the duke of Lower Pannonia, Ljudevit, as well as the Roman History (Historia Romana) by Velleius Paterculus and the Lives of Caesars (De vita Caesarum) by Suetonius Tranquillus (early 1 st and early 2 nd centuries AD), works that yield valuable information about the uprising of the two Batos. In particular, the connection between the Frankish sources and Suetonius's imperial biographies is explored, since the historiographical tradition of the so-called Carolingian Renaissance found its inspiration precisely in Suetonius's biographical history (one should remember Einhard's Life of Charlemagne, especially if one takes into account that Einhard was thought by older historiography to be one of the authors/editors of the Annales regni Francorum).

Both the Roman and Frankish sources that provide the information about the War of the Batos and the War against Liudewit, which are under scrutiny here, each look at these respective events from their own timelines and their own perspectives as undisputed sovereigns who, by their domination, guarantee peaceful state of affairs and general prosperity, therefore presenting any attempt to change the existing circumstances as blow to the right order of things. Their colonial discourse is rather obvious. Even when they seem to emphasize the virtues of their adversaries (regularly those are military virtues), or the difficulties associated with warfare against rebels and initial concerns, they do so to extol their own success.

At the narrative level, the dependence of Frankish authors on Roman literary patterns can be seen in the formation of narratives, which, in line with genre restrictions, is reflected in the borrowing of syntagms and conceptual sets. Whether or not there is also at work a more direct reliance by Frankish authors on their Roman counterparts in relation to geopolitical considerations (the coincidence of the area of the events) is difficult to say with certainty, but the analysis conducted here seems to indicate that Frankish authors were certainly aware of this. The 
strong personalisation of the Carolingian-age war in southern Pannonia - besides being more in tune with the spirit of the era since it was about a vassal who rose against his lord - may have also been due to the fact that a not sufficiently specific mention of the Pannonian war in the context of the time might lead readers to think that the area north of the river Drava was affected as well, the entire limes Pannonicus (ARF, a. 826). A debt to Roman models, in a way, is additionally paid here with the reference to the „Pannonian expedition“ (expeditio Pannonica, ARF, a. 821). It is certainly clear from the Frankish records that Ljudevit's uprising was the single most dramatic event in the history of the Carolingian dominance in the Danube-Adriatic area, which must have served as an additional trigger for Frankish authors to have before their eyes, as both a literary model and a political forerunner, the War of the Batos that the Romans themselves called their most serious conflict since the Punic Wars.

In the end, the epilogue and lesson of the story of both the Roman and Frankish accounts are, mutatis mutandis, identical and correspond to ideological posits of either empires: in both cases the rebels were defeated, their leaders justifiably punished, and the empires gained deserved triumphs. Anything less could (or should) have been hardly expected.

Keywords: Bellum Batonianum, bellum Liudewiticum, Roman historiography, Carolingian historiography, ideology, propaganda

Ključne riječi: Batonski rat, Ljudevitov rat, rimsko povijesno spisateljstvo, karolinško povijesno spisateljstvo, ideologija, propaganda

Hrvoje Gračanin Filozofski fakultet Sveučilišta u Zagrebu Ivana Lučića 3 10000 Zagreb hrvoje.gracanin@gmail.com 


\section{FILOZOFSKI FAKULTET SVEUČILIŠTA U ZAGREBU \\ ZAVOD ZA HRVATSKU POVIJEST \\ INSTITUTE OF CROATIAN HISTORY \\ INSTITUT FÜR KROATISCHE GESCHICHTE}

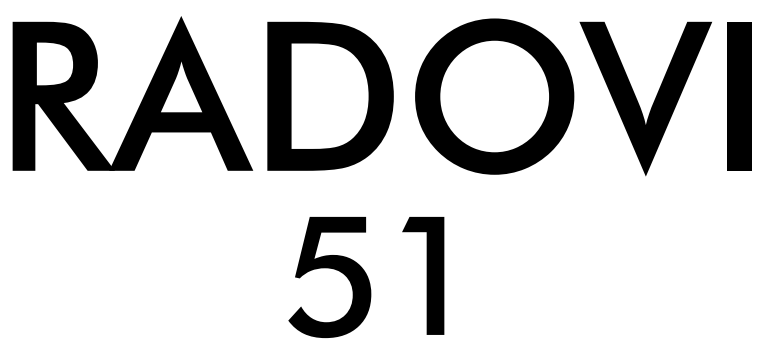

BROJ 2

ZAVOD ZA HRVATSKU POVIJEST

FILOZOFSKOGA FAKULTETA SVEUČILIŠTA U ZAGREBU

\section{FF press}

ZAGREB 2019. 


\title{
RADOVI ZAVODA ZA HRVATSKU POVIJEST FILOZOFSKOGA FAKULTETA SVEUČILIŠTA U ZAGREBU
}

\author{
Knjiga 51, broj 2
}

\author{
Izdavač / Publisher \\ Zavod za hrvatsku povijest \\ Filozofskoga fakulteta Sveučilišta u Zagrebu \\ FF-press \\ Za izdavača / For Publisher \\ Vesna Vlahović Štetić \\ Glavni urednik / Editor-in-Chief \\ Inga Vilogorac Brčić \\ Izvršni urednik / Executive Editor \\ Kornelija Jurin Starčević \\ Uredništvo / Editorial Board
}

Jasmina Osterman (stara povijest/ancient history), Trpimir Vedriš (srednji vijek/medieval history), Hrvoje Petrić (rani novi vijek/early modern history), Željko Holjevac (moderna povijest/ modern history), Tvrtko Jakovina (suvremena povijest/contemporary history), Silvija Pisk

(mikrohistorija i zavičajna povijest/microhistory and local history),

Zrinka Blažević (teorija i metodologija povijesti/theory and methodology of history)

Međunarodno uredničko vijeće / International Editorial Council

Denis Alimov (Sankt Peterburg), Živko Andrijašević (Nikšić), Csaba Békés (Budapest), Rajko

Bratož (Ljubljana), Svetlozar Eldarov (Sofija), Toni Filiposki (Skopje), Aleksandar Fotić

(Beograd), Vladan Gavrilović (Novi Sad), Alojz Ivanišević (Wien),

Egidio Ivetić (Padova), Husnija Kamberović (Sarajevo), Karl Kaser (Graz),

Irina Ognyanova (Sofija), Géza Pálffy (Budapest), Ioan-Aurel Pop (Cluj),

Nade Proeva (Skopje), Alexios Savvides (Kalamata), Vlada Stanković (Beograd),

Ludwig Steindorff (Kiel), Peter Štih (Ljubljana)

Izvršni urednik za tuzemnu i inozemnu razmjenu /

Executive Editor for Publications Exchange

Martin Previšić

Tajnik uredništva / Editorial Board Assistant

Dejan Zadro

Adresa uredništva/Editorial Board address

Zavod za hrvatsku povijest, Filozofski fakultet Zagreb, Ivana Lučića 3, HR-10 000, Zagreb Tel. ++385(0)1 6120191

Časopis izlazi jedanput godišnje / The Journal is published once a year

Časopis je u digitalnom obliku dostupan na / The Journal in digital form is accessible at Portal znanstvenih časopisa Republike Hrvatske „Hrčak“ http://hrcak.srce.hr/radovi-zhp

Financijska potpora za tisak časopisa / The Journal is published with the support by Ministarstvo znanosti, obrazovanja i športa Republike Hrvatske

Časopis je indeksiran u sljedećim bazama / The Journal is indexed in the following databases: Directory of Open Access Journals, EBSCO, SCOPUS, ERIH PLUS, Emerging Sources Citation Index - Web of Science 


\title{
Naslovna stranica / Title page by Marko Maraković
}

\section{Grafičko oblikovanje i računalni slog / Graphic design and layout Marko Maraković}

\author{
Lektura / Language editors \\ Samanta Paronić (hrvatski / Croatian) \\ Edward Bosnar (engleski / English)
}

Tisak / Printed by

Tiskara Zelina, Sv. Ivan Zelina

Naklada / Issued

200 primjeraka / 200 copies

Ilustracija na naslovnici

Muza Klio (Alexander S. Murray, Manual of Mythology, London 1898)

Časopis je u digitalnom obliku dostupan na Portalu znanstvenih časopisa Republike Hrvatske ,Hrčak“ http://hrcak.srce.hr/radovi-zhp

The Journal is accessible in digital form at the Hrcak - Portal of scientific journals of Croatia http://hrcak.srce.hr/radovi-zhp 